\title{
AL-QÃDA $\bar{A}$ \\ PERADILAN dan HUKUM KELUARGA ISLAM
}

\section{Nilai Keadilan dalam Syariat Poligami}

The Justice Value within Polygamy Syariah

Sippah Chotban

Dosen UIN Alauddin Makassar

Email : sippahchotban@gmail.com

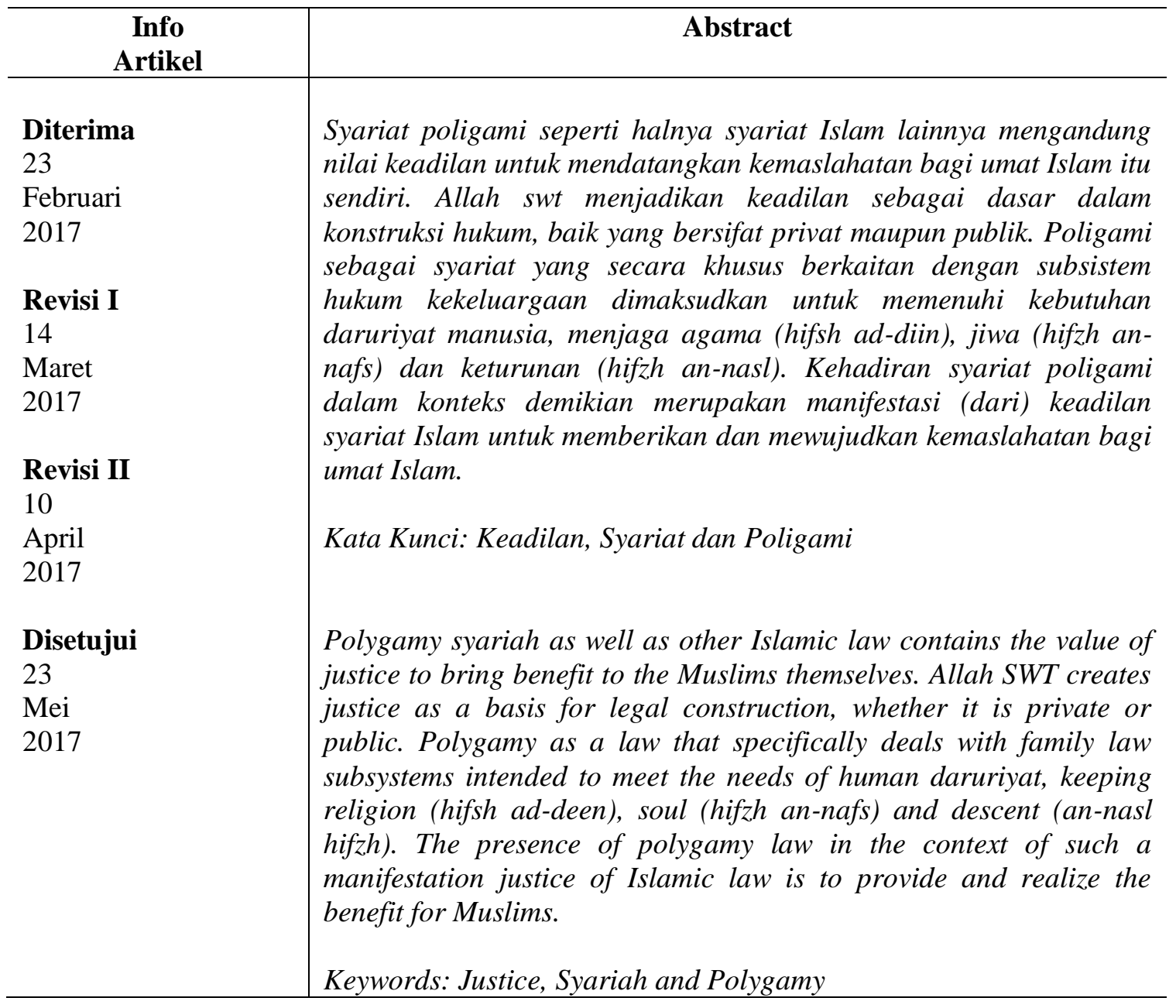




\section{PENDAHULUAN}

Keadilan dalam kaitannya dengan poligami sampai dengan saat ini masih terus dan senantiasa dipercakapkan, khususnya ketika melihat adanya problematika di seputar praktek poligami yang dilakukan oleh sebagian umat Islam. Secara sosiologis, sebagian besar mereka-mereka yang melakukan praktek poligami terlihat tidak dapat dengan baik mewujudkan keadilan syariat poligami dalam kehidupan rumah tangga. Sehingga darinya melahirkan pandangan hukum progresif mengenai poligami, ada yang menyatakan poligami baru bisa dilakukan ketika dalam kondisi darurat, ibaratnya orang yang berada dalam pesawat, baru bisa membuka pintu ketika kondisi pesawat (benar-benar) dalam keadaan darurat. Bahkan ada pula -yang berangkat dari fakta sosiologis terkait dengan praktik poligami- memandang poligami adalah mkruh dan haram untuk dilakukan. Namun, bersamaan dengan itu, jarang orang mempercakapkan nilai keadilan dalam syariat poligami. Karena itu, selanjutkan akan dibahas hal ihwal terkait.

\section{Konsepsi Keadilan dalam Syariat}

عata keadilan adalah kata jadian dari 'adil' yang berasal dari bahasa Arab عد yang berarti 'sama'. ${ }^{1}$ Persamaan tersebut sering dikaitkan dengan hal-hal yang bersifat immaterial. Kata 'adl adalah bentuk mashdar dari kata kerja 'adala - ya'dilu - 'adlan'udulan - wa 'adalatan (عدل - يعدل - عدلا - عدولا - و عدالة). Kata kerja ini berakar pada huruf-huruf 'ain, dal, dan lam, yang makna pokoknya adalah al-istiwa' dan al-i'waj. Rangkaian huruf-huruf tersebut mengandung makna yang bertolak belakang, yakni 'lurus' atau 'sama' dan 'bengkok' atau 'berbeda'. Dari makna pertama, kata 'adl berarti 'menetapkan hukum dengan benar'. Seorang yang 'adl berjalan lurus dan sikapnya selalu menggunakan ukuran yang sama, bukan ukuran ganda. 'Persamaan' itulah merupakan makna asal kata ' $a d l$, yang menjadikan pelakunya 'tidak berpihak' kepada salah seorang yang berselisih, dan pada dasarnya pula seorang yang 'adl 'berpihak kepada yang benar', karena baik yang benar maupun salah sama-sama memperoleh haknya. Dengan demikian, ia melakukan sesuatu yang patut dan tidak sewenang-

\footnotetext{
${ }^{1}$ Abi Husain Ahmad bin Faris bin Zakariyah, Mu'jam Muqayis fi al-Lughah (Beirut: Daral-Fikr, 1994), h. 745.

${ }^{2}$ Ibnu Mandzur, Lisan al- 'Arab, vol. 4 (t.t: Dar al-Ma’arif, 1979), h. 2838.
} 
wenang. ${ }^{3}$

Dalam bahasa Inggris, keadilan merupakan padanan kata justice, yang berasal dari kata just yang berarti having a basis in or conforming to fad or reason (mempunyai dasar dalam fakta atau sesuai dengan fakta atau akal) atau conforming to a standard of correctnes (cocok dengan standar tentang sesuatu yang betul) atau acting or being in conformity with what is morally upright or good (berbuat ada keadaan sesuai denga apa yang dipandang baik atau bagus secara moral). ${ }^{4}$ Sementara kata justice diterjemahkan ke dalam bahasa Indonesia menjadi keadilan yang bermakna 'lurus', 'konsisten', 'berimbang', 'sama' dan 'patut'. ${ }^{5}$ Dalam Kamus Besar Bahasa Indonesia, kata 'adil' memiliki beberapa arti: pertama, tidak berat sebelah atau tidak memihak; kedua, berpihak kepada kebenaran; dan ketiga sepatutnya tidak sewenang-wenang. ${ }^{6}$

Berdasarkan pada penjelasan etimologis dan terminologis di atas, dapat diambil kesimpulan bahwa keadilan adalah menempatkan sesuatu pada tempatnya (the righ man on the right place) dan memberikan apa yang menjadi milik seseorang dan mengambil apa yang menjadi haknya (i'tha al-mar'i ma lahu wa akhaza ma 'alaihy). Dengan kata lain, keadilan dalam istilah hukum berhubungan dengan hak yang harus diterima dan kewajiban yang harus ditunaikan. Dalam hukum Islam keadilan adalah sesuatu yang berimbang, tidak mesti selalu dalam pengertian sama berat (fifti-fifti), tetapi dalam pengertian harmonisasi antara bagian-bagiannya sehingga membentuk satu kesatuan yang harmonis.

Sementara kata syariah secara etimologis berarti "jalan tempat keluarnya air untuk minum". Kemudian bangsa Arab menggunakan kata ini untuk konotasi jalan lurus. Pada saat dipakai dalam pembahasan hukum menjadi bermakna "segala sesuatu yang disyariatkan Allah kepada hamba-hamba-Nya", sebagai jalan lurus untuk memperoleh kebahagian di dunia dan di akhirat. ${ }^{7}$

Kata syariah dalam bentuk mufrad (singular) terdapat dalam al-Quran surah al-

\footnotetext{
${ }^{3}$ Muchlis M. Hanafi, et. al. ed., Hukum, Keadilan dan Hak Asasi Manusia: Tafsir al-Qur'an Tematik (Jakarta: Lajnah Pentahshihan Mushaf al-Qur'an, 2010), h. 2-3.

${ }^{4}$ M. Karsayuda, Perkawinan Beda Agama: Menakar Nilai-Nilai Keadilan Kompilasi Hukum Islam (Cet. I; Yogyakarta: Total Media Yogyakarta, 2006), h. 26.

${ }^{5}$ Rifyal Ka'bah, Hukum Islam di Indonesia (Jakarta: Universitas Yasri,1999), h.28.

${ }^{6}$ Depertemen Pendidikan Nasional, Kamus Besar Bahasa Indonesia, Edisi III (Cet. II; Jakarta: Balai Pustaka, 2002), h. 8.

${ }^{7}$ Dede Rosyada, Hukum Islam dan Pranata Sosial: Dirasah Islamiyah III, (Cet. V; Jakarta: PT RajaGrafindo Persada, 1999), h. 2-3
} 
Sippah Chotban

Jatsiyah (45):18, sedangkan dalam bentuk jamaknya (plural), yang berbentuk syarai'ul islam, terdapat dalam sebuah Hadits yang diriwayatkan (HR) Ibnu Maja dari Abdullah bin Bisyr. Secara etimologis, kata "syariah” (asy-syari'ah) terbentuk dari kata syara'a yasra'u - syaria'atan/syar'an, yang mengandung dua makna yakni jalan lururs (atthariq al-musthaqim) dan sumber air (mawrid al-ma'li al-istisqa'). Secara terminologis atau menurut istilah, berrati "ketentuan hukum Allah yang diturunkan kepada Nabi dan Rasul untuk umatnya". Dalam kamus Marbawi, syariat diartikan "undang-undang atau hukum yang telah ditetapkan Allah swt untuk para hamba-Nya". ${ }^{8}$

Dilihat dari segi ilmu hukum, syariat merupakan norma hukum dasar yang ditetapkan Allah, yang wajib diikuti oleh orang Islam berdasarkan iman yang berkaitan dengan akhlak, baik dalam hubungannya dengan Allah maupun dengan sesama manusia dan benda dalam masyarakat. Norma hukum dasar ini dijelaskan dan atau dirinci lebih lanjut oleh nabi Muhammad sebagai Rasul-Nya. Oleh karena itu, syariat terdapat di dalam al-Qur'an dan di dalam kitab-kitab hadis. Karena norma-norma hukum dasar yang terdapat di dalam al-Qur'an itu masih bersifat umum, demikian juga halnya dengan aturan yang ditentukan oleh nabi Muhammad terutama mengenai muamalah, maka setelah Nabi Muhammad wafat, norma-norma hukum dasar yang masih bersifat umum itu perlu dirinci lebih lanjut. Perumusan dan pengolongan norma-norma hukum dasar yang bersifat umum itu ke dalam kaidah-kaidah yang lebih konkrit agar dapat dilaksanakan dalam praktik memerlukan disiplin ilmu dan cara-cara tertentu. Maka muncullah (disiplin) ilmu pengetahuan baru yang (secara) khusus menguraikan syariat yang dimaksud. Dalam kepustakaan, ilmu tersebut dinamakan (dengan) ilmu fiqh. Di sinilah letak kolerasi antara syariah dan fiqh.

Dalam syariat, keadilan dijadikan dasar dalam pembentukan dan pelakssanaan hukum. Bahkan keadilan dijadikan persyaratan dalam menentukan benar atau tidaknya, atau sah dan batalnya suatu pelaksanaan hukum. ${ }^{9}$ Menurut B.A. DAR dalam M. Karsayuda, patokan dalam hukum Islam adalah kebenaran dan keadilan. Keduanya harus dikembangkan dalam sikap, ucapan dan pengambilan keputusan. Kedua nilai ini harus diberlakukan untuk semua orang, sekalipun (untuk) musuh. Al-Qur'an berbicara

\footnotetext{
${ }^{8}$ H.M. Siradjuddin, Syariat Islam \& Agenda Umat, (Makassar: t.p, 2011), h. 3.

${ }^{9}$ Qurrotul Ainiyah, Keadilan gender dalam Islam: Konvensi PBB dalam Perspektif Mazhab Syafi'i (Malang: Kelompok Lintas Publishing, 2015), h. 27.
} 
mengenai keadilan dan kebenarn melalui QS al-Baqarah/2:176, QS al-Nisa'/4:58, 135 dan 170, QS at-Taubah/9:45, QS al-Maidah/5:8 dan QS al-An'am/6:56.

Keadilan juga dimaknai sebagai perpaduan harmonis antara hukum dengan moralitas. Kehadiran Islam beserta hukumnya tidak bertujuan untuk menghancurkan kebebsan individu, akan tetapi mengontrol kebebasan itu demi keselarasan dan keharmonisan masyarakat yang terdiri dari individu itu sendiri. Hukum Islam memiliki peran dalam mendamaikan pribadi dengan kepentingan kolektif, bukan sebaliknya. Individu diberi hak untuk mengembangkan hak pribadinya dengan syarat tidak menggangu kepentingan orang banyak. ${ }^{10}$ Selain itu juga hukum Islam mengatur kewajiban individu, sehingga proses aktualisasi hak tidak merusak kewajiban asasi (individu) di dalamnya.

Konsep keadilan demikian adalah ideal moral yang diajarkan al-Qur'an. Tuhan memerintahkan agar manusia bersikap adil di antara sesama, dalam mengadili di antara manusia hendaknya mengadili dengan adil (QS Al-A'raf/7:29; QS Al-Nahl/16:90; dan QS Al-Syuraa/26:15), karena Ia mencintai orang-orang yang mengadili suatu perkara dengan dan secara adil (QS Al-Nisa'/4:58). Seluruh orang beriman mempertahankan keadilan, meski hal itu merugikan diri sendiri, orang tua, sahabat dan sanak famili mereka, tanpa membedakan kaya miskin (QS Al-Maidah/5:45). Wahyu itu sendiri merupakan pengejawantaan dari kebenaran dan keadilan (QS Al-Nisa'/4:135), dan diturunkan bersama mizan atau keseimbangan (yang benar dan yang salah), oleh karena itu manusia harus menegakkan keadilann (QS al-Hadid/57:25). Keadilan bernilai mutlak dan secara moral mengikat, karena itu orang-orang beriman diperingatkan agar tidak membiarkan kebencian terhadap seseorang menyebabkan mereka melanggar batas-batas keadilan (QS Al-Maidah/5:3), atau membuat diri nmereka menyeleweng dari ideal keadilan, karena keadilan sangat dengan ketakwaan dan kebenaran (QS AlMaidah/5:9). ${ }^{11}$

Prinsip keadilan tersebut mencakup berbagai aspek hubungan, baik hubungan antar individu, hubungan dalam keluarga, serta hubungan dalam masyarakat dan negara. Juhaya S. Praja mengatakan bahwa term keadilan pada umumnya berkonotasi pada

\footnotetext{
${ }^{10}$ Lihat Muhammad Erwin, Filsafat Hukum: Refleksi Kritis Terhadap Hukum, Edisi I (Cet. II; Jakarta: Rajawali Press, 2012), h. 224.

${ }^{11}$ Lihat M. Karsayuda, Perkawinan Beda Agama: Menakar Nilai-Nilai Keadilan Kompilasi Hukum Islam, h.50-51.
} 
penetapan hukum atau kebijakan penguasa. Akan tetapi, keadilan dalam hukum Islam meliputi berbagai aspek kehidupan, khususnya di bidang hukum dan peradilan. ${ }^{12}$ Jadi, hukum Islam yang mengatur hubungan manusia dengan Allah (ahkam al-ibadah) dan hubungan sesama manusia (ahkam muamalah) adalah manifestasi konsep keadilan hukum Islam.

Dengan demikian, syariat Islam adalah syariat yang dibangun di atas keadilan dan sekaligus merefleksikan keadilan itu sendiri. Keadilan sebagai sesuatu yang berimbang tidak mesti selalu dalam pengertian sama berat, tetapi juga dalam pengertian harmonisasi antara bagian-bagian atau pihak-pihak sehingga membentuk suatu kesatuan yang harmonis. ${ }^{13}$

\section{Konsepsi Poligami dalam Syariat}

Dalam konsepsi syariat, poligami merupakan salah satu bagian dari syariat perkawinan yang mengatur hal ihwal perkawinan seorang suami lebih dari satu hingga sampai empat sebagaimana batas yang ditetapkan syariat. Poligami secara etimologis berasal dari bahasa Yunani yang terdiri dari dua kata, yaitu poly/polus yang berarti banyak, dan kata gamie/gamos yang berarti kawin/perkawinan. ${ }^{14}$ Dalam Kamus Bahasa Indonesia, poligami diartika sebagai (suatu) sistem perkawinan yang membolehkan laki-laki mempunyai istri lebih dari satu orang dalam waktu yang beersamaan. ${ }^{15}$ Dengan demikian, poligami adalah perkawinan laki-laki lebih dari satu.

Secara historis, praktek poligami bukan baru dilaksankan pertama kali oleh umat Islam semenjak turun syariat poligami, melainkan jauh sebelumnya sudah dipraktekkan oleh agama dan peradaban lain. Bahkan ada informasi bahwa agama dan peradaban sebelumnya bukan saja mempraktekkan poligami, akan tetapi (juga) "mentradisikan" poligami. Dalam agama Hindu, praktek poligami dilakukan sejak zaman Bahari dengan tidak mengenal batasan tertentu mengenai jumlah perempuan yang boleh dikawini. Bahkan seorang Brahma yang berkasta tinggi sampai sekarang boleh mengawini siapa pun yang disukainya tanpa adanya pembatasan. Hal tersebut

\footnotetext{
${ }^{12}$ Juhaja S. Praja, Filsafat Hukum Islam (Bandung: LPPM Universitas Islam, 1995), 72.

${ }^{13}$ Rifyal Ka'bah, Politik \& Hukum dalam al-Qur'an (Jakarta: Penerbit Khairul Bayan, 2005), h. 87.

${ }^{14}$ Abdul Bari Syaifuddin, Ensiklopedia Indonesia, Edisi Khusus (Jakarta: Ichtiar Baru van Havea, tt), h. 2734.

${ }^{15}$ Depertemen Pendidikan Nasional, Kamus Besar Bahasa Indonesia, h. 1119.
} 
juga membudaya dan melembaga pada masyarakat Israel sebelum datangnya nabi Musa as. Kebiasaan tersebut kemudian diupayakan oleh Talmud di yerusalem untuk dihapuskan dengan ketentuan poligami dilakukan berdasarkan kemampuan dalam menjaga dan merawat perempuan yang dikawini. Namun, usaha tersebut gagal dikarenakan kaum Kairat tidak mengakuinya. Sementara pada orang Persi, kebiasaan memiliki lebih dari seorang istri akan mendapatkan hadia. Begitu pula agama Yahudi membolehkan praktek poligami tanpa batasan tertentu. ${ }^{16}$ Praktek poligami tanpa batas ini pun mermbah sampai pada peradaban lain bahkan masyarakat arab Jahiliyah.

Islam dengan prinsip keadilannya datang mengatur pola perkawinan poligami yang sudah membudaya dan melembaga dalam kehidupan masyarakat dengan tidak melarang dan juga tidak memerintahkan secara mutlak, melainkan mengat ur dalam arti memberikan batasan kebolehan perempuan yang dipoligami oleh seorang lakilaki/suami dengan syarat-syarat yang ditentukan. Hal ini sebagaimana termaktub dalam QS al-Nisa'/4:3

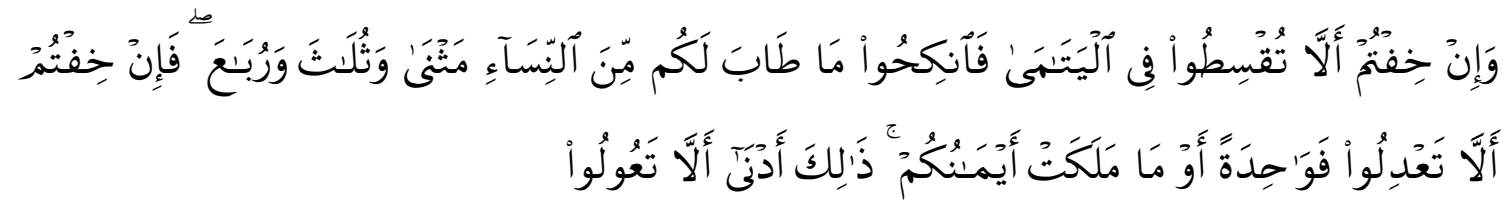

Terjemahnya:

"Dan jika kamu takut tidak akan dapat berlaku adil terhadap (hak-hak) perempuan yatim (bilaman kamu mengawininya), maka kawinilah wanitawanita (lain) yang kamu senangi: dua, tiga atau empat. Kemudian jika kamu takut tidak akan dapat berlaku adil, maka (kawinilah) seorang saja, atau budakbudak yang kamu miliki. Yang demikian itu adalah lebih dekat kepada tidak berbuat aniaya. ${ }^{17}$

Dalam menjelaskan QS al-Nisa'/4:3 tersebut terdapat banyak pandangan, ${ }^{18}$

\footnotetext{
${ }^{16}$ Sulaiman al-Kumayi, Aa Gym di Antara Pro-Kontra Poligami (Cet. I; Semarang: Pustaka Adnan, 2007), h. 14-15.

${ }^{17}$ Depertemen Agama RI, Al-Qur'an dan Terjemahannya (Cet. I; Semarang: Toha Putra, 1989), h. 115 .

${ }^{18}$ Pandangan yang mengatakan bahwa: (a) poligami dilarang secara mutlak; (b) poligami dilarang dengan syarat tidak karena darurat; (c) poligami dibenarkan (mubah) tanpa batas; (d) poligami dibenarkan sampai sebanyak 18 orang orang perempuan; (e) poligami dibenarkan sampai sejumlah 9 orang perempuan; dan (f) poligami dibenarkan sampai 4 orang perempuan saja. Untuk lebih lanjutnya
} 
namun pada substansinya QS al-Nisa'/4:3 memberikan informasi mengenai ketentuan hukum poligami, mulai dari status hukumnya, syarat dan juga batasan perempuan yang hendak dipoligami. Dari aspek status hukumnya, poligami hukum dasarnya adalah mubah (boleh). Imam Syafi'i menyatakan bahwa QS al-Nisa'/4:3 membolehkan ${ }^{19}$ lakilaki menikah sampai empat orang perempuan. ${ }^{20}$ Hukum dasar poligami ini menurut sebagian fuqoha'(ahli fikih) sama dengan hukum pernikahan, yang kembalinya kepada lima kategori hukum, yaitu: (a) fardh/wajib, apabila poligami tidak dilaksanakan, suami akan jatuh kepada keharaman, seperti perbuatan zina, selingkuh dan perbuatan asusila lainnya; (b) mustahab/sunnah, apabila suami mampu dan memiliki harta yang cukup untuk melakukan poligami, dan dia melihat ada beberapa wanita muslimah (janda misalnya) yang sangat perlu dinikahi untuk diberikan pertolongan padanya.;p (c) mubah/boleh, apabila suami berkeinginan untuk melakukan poligami dan ia cukup mampu untuk melakukannya; (d) makruh, apabila suami berkeinginan untuk melakukan poligami sedangkan ia belum memiliki kemampuan yang cukup sehingga akan kesulitan di dalam berlaku adil; dan (e) haram, apabila poligami dilakukan atas dasar niat yang buruk, seperti untuk menyakiti isteri pertama dan tidak menafkahinya, atau ingin mengambil harta wanita yang akan dipoligaminya, atau tujuan-tujuan buruk lainnya. $^{21}$

Sementara syarat poligami adalah (berlaku) adil ${ }^{22}$ dan juga adanya persetujuan istri serta adanya kepastian bahwa suami mampu menjamin keperluan hidup istri-istri dan anak-anak mereka. ${ }^{23}$ Dan batasan perempuan yang hendak dipoligami sebagaimana dikatakan oleh Imam asy-Syafi'i dalam kitabnya al-Umm, adalah empat orang perempuan. Bentuk pengaturan syariat Islam mengenai poligami ini mulai dari status hukum, syarat dan batasan perempuan yang raus dipoligami sebagaimana yang

lihat M. Thahir Maloko, Poligami dalam Pandangan Orientalis dan Perspektif Hukum Islam (Cet. I; Makassar: Alauddin University Press, 2011), h. 63-68.

${ }^{19}$ Mengenai status hukum pun terjadi perbedaan pandangan. Untuk lebih lanjutnya lihat Halimah B. Perempuan dalam tafsir Modern: Kajian Tafsir at-Tahrir wa al-Tanwir Karya Muhammad Tahir Ibnu Asyur (Cet. I; Makassar, Alauddin University Press, 2013), h. 180-218.

${ }^{20}$ Muhammad ibn Idris al-Syafi'i, Al-Umm, Vol V (Bairut: dar al-Fikr, 1990), h. 44.

${ }^{21}$ Lihat Abu Salma al-Atsari, Poligami Dihujat (dalam bentuk aplikasi HTTL)

${ }^{22}$ Direktoral Pembinaan Badan Peradilan Agama Depertemen Agama, Kompilasi Hukum Islam di Indonesia, h. 35.

${ }^{23}$ Direktoral Pembinaan Badan Peradilan Agama Depertemen Agama, Kompilasi Hukum Islam di Indonesia, h. 36. Dan lihat penjelasan lebih lanjut pada M. Thahir Maloko, Poligami dalam Pandangan Orientalis dan Perspektif Hukum Islam (Cet. I; Makassar: Alauddin University Press, 2011), h. 48-60. 
dijelaskan sebelumnya adalah bentuk manifestasi dari keadilan syariat islam.

\section{Nilai Keadilan dalam Syariat Poligami}

Poligami sebagai bagian dari syariat merupakan manifestasi dari keadilan syariat Islam pada umumnya. Keadilan tersebut tidak hanya terletak pada dasar dan prinsipnya (sebagai syariat), akan tetapi (juga) terefleksi dan termanifestasi dalam aspek-aspek kehidupan sosiologis umat. Artinya bahwa keadilan syariat poligami tidak terlepas dari konteks sosiologis umat Islam. Allah mensyariatkan poligami bagi umat Islam, karena memang ada kondisi-kondisi tertentu yang akan dialami oleh pasangan suami istri yang pada akhirnya menghendaki (suami) kawin lagi (baca: berpoligami). Tidak mungkin dalam kondisi istri sakit berat (yang tidak dapat disembuhkan) dan mandul serta mengizinkan suaminya untuk berpoligami, misalnya, seorang suami dilarang untuk melakukan poligami. ${ }^{24}$ Tidak mungkin juga syariat Islam yang asysyumul tidak menyediakan seperangkat aturan hukum yang mengatur kemungkinankemungkinan demikian. Syariat Islam dengan keadilannya tentunya mengatur hal demikian, sebagaimana yang dijelaskan pada pembahasan sebelumnya. Karena itu, teramatlah naif jika syariat poligami dinafikan secara mutlak dalam kehidupan umat Islam hanya karena sebagian fakta sosiologis membuktikan terjadi penyimpangan dalam praktek poligami.

Nilai keadilan dalam syariat poligami sebenarnya sudah terakomodir dalam ayat poligami dan munasabah ayatnya serta penjelasan para ulama. Bahkan dalam Kompilasi Hukum Islam (KHI) pun dijelaskan nilai keadilan dalam syariat poligami, yang darinya menjadi pertimbangan khusus dalam membolehkan seorang suami untuk berpoligami. Dalam ayat poligami beserta munasabahnya (QS al-Nisa'/4:2-3) dapat dilihat bahwa syariat poligami terkait dengan kondisi anak yatim. Artinya syariat poligami hendak menyelamatkan kondisi anak yatim. Meskipun syariat poligami dalam kaitannya dengan ini bukan satu-satunya cara untuk menolong dan menyelamatkan kondisi anak yatim, akan tetapi hanya (menjelaskan) salah satu syariat Islam (dari sekian banyak syariat) yang memiliki (nilai) keadilan terhadap anak yatim. Sehingga

\footnotetext{
${ }^{24}$ Pandangan ini secara implisit ditolak oleh Musda Mulia, dengan alasannya bagaimana kalau yang mengalami kekurangan itu adalah suami. Oleh karena itu, Musdah menawarkan solusi untuk bersabar dalam kondisi demikian. Lihat Siti Musdah Mulia, Muslimah Sejati: Menenmpuh Jalan Islami Meraih Ridha Ilahi (Cet. I; Bandung: Marja, 2011), h. 204.
} 
bisa saja ditempuh dengan cara-cara lain yang dibenarkan syariat, pun juga bisa dengan cara berpoligami, asalkan dalam prakteknya memperhatikan aspek-aspek keadilan yang harus diwujudkan di dalamnya.

Dalam KHI bab IX tentang beristri lebih dari satu orang pada pasal 57 dijelaskan bahwa poligami baru diizinkan untuk dilaksanakan apabila: (a) istri tidak dapat menjalankan kewajiban sebagai istri; (b) istri mendapat cacad badan atau penyakit yang tidak dapat disembuhkan; dan (c) istri tidak dapat melahirkan keturunan. ${ }^{25}$ Ketiga ketentuan syarat (lain) untuk melakukan poligami ini, yang mengandung nilai keadilan objektif adalah poin $\mathrm{b}$ dan c. Sementara poin a, tidak musti untuk dilakukan poligami, sebab ada ketentuan hukum lainnya diseputar perkara itu, berupa nusyuz. Meskipun demikian, harus diakui ketiga masalah ini seringkali terjadi dalam kehidupan sosiologis rumah tangga. Biasanya ketika ada persoalan hukum baru yang muncul dalam kehidupan sosiologis umat, syariat memberikan ruang ijtihad bagi para mujtahid untuk melakukan penemuan hukum terhadap persoalan hukum yang tidak terdapat ketentuan hukum yang jelas dan pasti dalam mashadir al-ahkam (sumber primer syariat Islam). Namun, dalam kaitannya kasus ini semacam ada tawaran solusi bagi pasangan suami istri yang sama-sama mengizinkan suaminya berpoligami. Tentu, aspek ini adalah konkritisasi sekaligus manifestasi keadilan syariat Islam khususnya syariat poligami. Bayangkan bagaimana jika dalam suatu rumah tangga seorang suami mendapati istrinya mengalami kondisi $\mathrm{b}$ dan $\mathrm{c}$ bersamaan dengan itu ada kehendak suami dan juga izin istri untuk memberikan suaminya berpoligami, sementara itu tidak ada ketentuan hukum yang mengatur dan mengizinkannya. Tentunya sesuatu yang tidak bisa dibayangkan, meskipun lagi-lagi ada ruang ijtihad untuk menemukan hukum di dalamnya.

Belum lagi jika kehendak suami disertai dengan (tuntutan) kebutuhan alami sebagai manusia normal untuk menyalurkan hasrat seksualitasnya pada tempat yang ideal dan dibenarkan oleh syariat. Lagi-lagi tidak mungkin dibiarkan begitu saja kebutuhan alami tersebut tanpa terakomodir ke dalam suatu perangkat aturan hukum. Bisa-bisa akan mengakibatkan lahir dan terjadinya penyimpangan hasrat seksualitas.

\footnotetext{
${ }^{25}$ Direktoral Pembinaan Badan Peradilan Agama Depertemen Agama, Kompilasi Hukum Islam di Indonesia (t.t.p: t.p, 1991/1992), h. 36.
} 
Inilah mengapa perselingkuhan bahkan pelacuran pun sering terjadi dilakukan oleh seorang suami yang mendapati kondisi istrinya dalam keadaan normal, karena memang ada kondisi di mana hasrat seksualitas halalnya seorang suami tertekan oleh kondisi yang dialami oleh seorang istri, misalnya, haid dan hamil. Apatah lagi kalau kondisi istri memang sudah dalam keadaan tidak normal. Di sinilah urgensitas dan keadilan syariat poligami itu. Syariat yang (sangat) sesuai dengan kebutuhan manusia. Perlu untuk ditekankan di sini bahwa syariat poligami tersebut bukan soal "kelainan seks" sebagaimana yang dituduhkan kebanyakan orang. Juga bukan sebuah legitimasi subordinasi dan diskriminasi terhadap seorang perempuan. Akan tetapi syariat poligami sama halnya dengan syariat perkawinan pada umumnya yang antara lain disyariatkan untuk meminimalisir sekaligus mengakomodasi hasrat seksualitas seorang laki-laki bahkan perempuan malahan.

Meskipun syariat poligami mengandung nilai keadilan, tidak serta merta menjadikan poligami menjadi wajib hukumnya untuk dilaksanakan begitu saja oleh seorang suami, melainkan ada syarat yang perlu untuk diperhatikan dan dipertimbangkan dengan matang, yakni (berlaku) adil ${ }^{26}$ dan juga adanya persetujuan istri serta adanya kepastian bahwa suami mampu menjamin keperluan hidup istri-istri dan anak-anak mereka. ${ }^{27}$ Semuanya itu semata untuk menjaga keutuhan rumah tangga. Keadilan syariat poligami tidak akan membuat praktek poligami menjadi adil dan berkeadilan, manakala suami sebagai seorang mukallaf dalam praktek berpoligami tidak berjiwa dan berlaku adil. Dan tidaklah hasrat untuk berpoligami dibiarkan begitu saja tanpa ada aturan hukumnya. Di sinilah elaborasi keadilan sebagai prinsip dasar syariat poligami dan syarat/praktek poligami (itu sendiri). Olehnya, status hukum (ber)poligami dikembalikan pada kondisi seorang mukallaf yang melakukan, sehingga bisa saja sunnah dan wajib atau malahan makruh dan haram atau hanya sekedar pilihan (boleh). Yang terpenting adalah kita harus adil dalam mengungkap keadilan syariat poligami dan merumuskan keadilan sebagai syarat poligami.

\footnotetext{
${ }^{26}$ Direktoral Pembinaan Badan Peradilan Agama Depertemen Agama, Kompilasi Hukum Islam di Indonesia, h. 35.

${ }^{27}$ Direktoral Pembinaan Badan Peradilan Agama Depertemen Agama, Kompilasi Hukum Islam di Indonesia, h. 36.
} 


\section{PENUTUP}

Syariat poligami adalah syariat yang adil dan berkeadilan, yang disyariatkan untuk memenuhi kebutuhan sekaligus kemaslahatan umat manusia. Ia bukan syariat merebut, menguasai, mensubordinasi dan mendiskriminasi seorang perempuan. Juga tidak langsung dilaksanakan begitu saja oleh seorang mukallaf, melainkan harus memperhatikan dan mempertimbangkan syarat yang telah ditetapkan dalam syariat, yakni (berjiwa dan berlaku) adil dan berkeadilan.

\section{DAFTAR PUSTAKA}

Ainiyah, Qurrotul. Keadilan gender dalam Islam: Konvensi PBB dalam Perspektif Mazhab Syafi'i. Malang: Kelompok Lintas Publishing, 2015.

B., Halimah. Perempuan dalam tafsir Modern: Kajian Tafsir at-Tahrir wa al-Tanwir Karya Muhammad Tahir Ibnu Asyur. Cet. I; Makassar, Alauddin University Press, 2013.

Depertemen Agama RI, Al-Qur'an dan Terjemahannya. Cet. I; Semarang: Toha Putra, 1989.

Direktoral Pembinaan Badan Peradilan Agama Depertemen Agama, Kompilasi Hukum Islam di Indonesia. t.t.p: t.p, 1991/1992.

Erwin, Muhammad. Filsafat Hukum: Refleksi Kritis Terhadap Hukum. Edisi I. Cet. II; Jakarta: Rajawali Press, 2012.

Maloko, M. Thahir. Poligami dalam Pandangan Orientalis dan Perspektif Hukum Islam. Cet. I; Makassar: Alauddin University Press, 2011.

Muhammad ibn Idris al-Syafi'i, Al-Umm. Vol V. Bairut: dar al-Fikr, 1990.

Mulia, Siti Musdah. Muslimah Sejati: Menenmpuh Jalan Islami Meraih Ridha Ilahi. Cet. I; Bandung: Marja, 2011. 